\begin{tabular}{|c|c|c|}
\hline Received: July 2018 & Accepted: October 2018 & Published: October 2018 \\
\hline \multicolumn{2}{|c|}{ Article DOI: http://dx.doi.org/10.24903/sj.v3i2.232 } \\
\hline
\end{tabular}

\title{
Developing A Supplementary Material Of Malay Tourism For Vocational Students In Pontianak West Kalimantan
}

\author{
Nur Rahmiani \\ Academy of Midwifery 'Aisyiyah Pontianak \\ nur.rahmiani15@gmail.com \\ Urai Salam \\ Tanjungpura University \\ urai.salam@gmail.com \\ Iwan Supardi \\ Tanjungpura University \\ iwan.supardi26@gmail.com
}

\begin{abstract}
This study develops a supplementary material of Malay Tourism suitable for vocational tourism students (VTS) in Pontianak, Indonesia. The study focuses on the specific product phases consisting of analysis, design, development, and evaluation. The need analysis reveals that VTS need a particular material supporting tourism industry that can cover the skills of English and enhance their motivation and activities of learning English. Based on the design and development process, the product provides five units of learning materials namely introduction; cultural sites; festivals and attractions; arts and crafts; and transportation and accommodation that those parts are covering the content of Malay tourism and supporting facilitation. All of the components represent the findings of the analysis process. The product also provides appropriate pictures, instructional guides, maps, grammar guide, and words of wisdom in which packed in a travel guidebook. The evaluation is conducted to secure the suitability and the responses of the participants using the validator, the teacher and students questionnaire that this supplementary material meets the need for the tenth-year students at SMK Pariwisata CBK Pontianak. The evaluation also provides the feedback from the participants in the revision process.
\end{abstract}

Keywords: Developmental research, Malay tourism, ESP, vocational education 


\section{INTRODUCTION}

The study addresses the issue of the existence of English course for vocational tourism education (VTE) in Pontianak, West Kalimantan and the materials used in the course. VTE provides classes to prepare students for their future career jobs related to the tourism industry. It is understood that the use of materials in the courses offered by VTE seems likely to have little coverage with regards to specific topics related to the tourism industry. Furthermore, Vocational tourism students (VTS) need to be equipped with enough information about tourism, e.g., the tourist spots, accommodations, and facilitation. They need to be prepared to be a part of skilled personnel in the tourism industry, e.g., hospitality administration, travel agent, tourism office, and other related job opportunities.

For the mentioned reasons, some previous research addressing English teaching materials have been observed. A study for a diploma tourism institution is found and designed for diploma students in Medan as a part of preparing the students habituating the terms of tourism in ESP (Ulfa, 2015). Wahyukti \& Pujiatno (2015) develop an English module in particular materials of speaking skills regarding tourism for VTS. A few other researchers do not touch on the terms of tourism but rather assist teaching materials for nonvocational institutions (Kasmawita, Ikhsanuddin, \& Salam, 2015). Another important study is found on reading material of the local legends appropriate to help students improve their English skills using information of local contents of Dayak (Ridwan, Sofian, \& Salam, 2014).

As this work is different from the previous works in some cases, it is a full package of teaching materials specific for vocational tourism students intended to support particular purposes including accustoming them of the ESP tourism terms in the level of the senior high school. The product is accessible which can be operated using computers or manually and within the genre of Malay of West Kalimantan content. The work is inspired by the awareness of the tourism vocational school in West Kalimantan of the need of an accessible teaching material that may give information about local cultures for students.

The researcher might limit the tourism information on Malay cultures only related to the researcher capacity reason with regards to the number of cultural destinations in West Kalimantan. More than $50 \%$ of districts or cities have historical of Malay cultures including in Pontianak, Ketapang, Sambas, Mempawah, Kubu Raya, Landak, and Sanggau (Dinas Pariwisata \& Ekonomi Kreatif Kalbar, 2014; Tourism \& Creative Economy Service West Kalimantan Province, 2014; 2017). This issue is confirmed by Ahyat (n. d.) stating that the Malays in West Kalimantan occupies in two large communities namely coastal (Sambas, 
Mempawah, Landak, Pontianak, Ketapang, and Sukadana) and inland communities Sanggau, Sekadau, Sintang, Melawi, and Putusibau. Another reason is the limited written information available to Malay attractive destinations that have been separated from the different materials based on the observation at the library and marketing area. If an English teacher wants to introduce the content to the students, the information has not been in the convincing design for VTS.

For this opportunity, the researcher utilizes the theory of ESP (English for Specific Purposes) that can be adapted to developing supplementary materials. Materials mean kinds of teaching facilitations (books, media, CD, and so on) that have a purpose empower teaching-learning program (Tomlinson, 2007; 2011). Focusing on VTE, an ESP work is needed, especially in a different format from general English (Johns and Machado, 2001). ESP is a particular model of English which have consisted of it is designed to meet the specified needs; related to content based on the area of discipline, occupations or activities; stressed on the appropriate language used to several events (Johns and Machado, 2001). By those definitions, the red line of ESP is collecting program of teaching English in specific learning by using of suitable lexis and context based on the needs and the goals of students in separated programs. The critical point is the need analysis as a specific way to identify the course program.

In this study, therefore, the position of vocational tourism, English is concerned with the language of tourism training dealing with finding job and interview skills (Dudley-Evans \& M. J. St John, 2011). Tourism is a sophisticated industry sector that serves specific products and services for people participating in activities in places other than their residence (Christou, 2005). As stated by Munsters \& de Klumbis (2005), there are two main products of tourism that the curriculum of vocational schools has been cited in the part of the syllabus. These are including the core product consists of the physic of cultural building and attraction (monuments, museums, palaces and cultural events) plus the related specific cultural tourist services, such as information and education rendered, for example, by museum guides and palace guides. Then supplement product consists of the general tourist product elements, either apart from or incorporated into the cultural attraction itself, composed of public service and transportation.

Those products have a potential link to culture. More products of the tourism industry have more connection the culture of native society. Thus, this is true if the concept of learning is affected by culture. Focusing on tourism vocational schools, it has its unique 
students' background. Therefore, to cover the goals of learning English and the objectives of institutions, the institution enhances the opportunity of developing additional materials of tourism information that is formatted in a package of the travel guidebook.

\section{METHODOLOGY}

The design of this study applies developmental research using specific project phases consist of analysis, design, development, and evaluation (Richey \& Klein, 2007). This study uses the setting of the private institution of tourism vocational school in Pontianak city (SMK Pariwisata CBK Pontianak) for gaining the data in the need analysis and implementing the product. Moreover, the researcher cooperates participants or informants for particular purposes through interviews and questionnaires. . First, they are an English teacher and Malay native speakers. They are the key informants for gathering data of Malay Tourism Destination and elements of English teaching materials. Second, the tenth-year students at SMK Pariwisata CBK Pontianak and their English teacher consisting of two classes namely Travel Agent (13 students) and Hospitality Administration class (36 students). They participate in giving the response to the suitability of the product. Third, an expert validator responds and evaluates the supplementary material both the content and the context of ESP.

Two kinds of questionnaires are delivered in similar processing. Questionnaires both students' and teacher' response to the trial process and experts validation questionnaire are analyzed similarly using descriptive analysis (Kothari, 2004). Measurement of questionnaire uses multi-dimensional analysis, specifically using Measure of Central Tendency. In the other hand, the data from interviews are analyzed using the six-steps of data analysis based on Creswell (2012, pp.261-262). First, the researcher prepares and organizes the data for analyzing by organizing the data and transcribing interviews. Second, the process of coding is reducing a text or image database to descriptions and themes of people, places, or events. Third, the researcher codes and develops the description by making strength in the point of cases. Fourth, the researcher represents and reports the findings in narrative and tables. Fifth, the researcher interprets the findings. Even the findings that are not something that breaks the privacy issues (highly confidential), the researcher interprets the meaning by making comparisons between the findings and study literature. The last, the researcher validates the accuracy of the findings by triangulation. 


\section{FINDINGS AND DISCUSSION}

The researcher provides five important findings based on the findings.

\section{Analysis Process}

In this study, the researcher interviews an English teacher who teaches in vocational Tourism CBK Pontianak and two sources from MABM West Kalimantan (Majelis Adat Budaya Melayu-Council of Indigenous Malay Culture of West Kalimantan. The table below is findings of English Teacher' interview about the needs of material in the point of view both aspect of ESP and the criteria of the book.

\begin{tabular}{|c|c|c|c|}
\hline \multirow{2}{*}{\multicolumn{2}{|c|}{$\begin{array}{l}\text { Aspect of ESP } \\
\text { Comparing with general } \\
\text { students at senior high school, } \\
\text { the students of the year-tenth } \\
\text { are more mature in critical } \\
\text { thinking to split the time taking } \\
\text { class and working. Furthermore, } \\
\text { English is still as an ambitious } \\
\text { subject even they need this } \\
\text { language for obligatory. }\end{array}$}} & \multicolumn{2}{|c|}{ Criteria of Travel Guidebook } \\
\hline & & Output & $\begin{array}{l}\text { The book is generally } \\
\text { intended as an interesting } \\
\text { English course book, } \\
\text { completed with all of } \\
\text { English skills and its } \\
\text { complement. }\end{array}$ \\
\hline $\begin{array}{l}\text { Language } \\
\text { information } \\
\text { about target } \\
\text { situation }\end{array}$ & $\begin{array}{l}\text { The level of English students' } \\
\text { capabilities is more than fifty } \\
\text { percent in the beginner level. }\end{array}$ & \multirow[t]{2}{*}{ Segmentation } & \multirow{2}{*}{$\begin{array}{l}\text { The users are high school } \\
\text { teens. Thus, the book may } \\
\text { be suitable with the users } \\
\text { in order to support and } \\
\text { fulfill the curriculum } 2006 \\
\text { and to introduce Malay } \\
\text { tourism of West } \\
\text { Kalimantan. }\end{array}$} \\
\hline Learners' lacks & $\begin{array}{l}\text { The point of difficultness is on } \\
\text { the vocabulary so that the } \\
\text { students face up the } \\
\text { difficultness in all aspects of } \\
\text { English skill. }\end{array}$ & & \\
\hline $\begin{array}{l}\text { Learners need } \\
\text { from course }\end{array}$ & $\begin{array}{l}\text { English is used in tourism term. } \\
\text { Thus, the students have to be } \\
\text { mastered in English to help } \\
\text { them reaching the competencies } \\
\text { and job vacancy (for long-term } \\
\text { impact). }\end{array}$ & \multirow[t]{2}{*}{ Visual concept } & \multirow[t]{2}{*}{$\begin{array}{l}\text { The book may be } \\
\text { equipped of related } \\
\text { pictures, full color and } \\
\text { supplement } \\
\text { designing in visual } \\
\text { attractive. }\end{array}$} \\
\hline $\begin{array}{l}\text { Language } \\
\text { learning needs }\end{array}$ & $\begin{array}{l}\text { The education system at } \\
\text { research study uses curriculum } \\
\text { 2006. English book and other } \\
\text { materials are suited to the } \\
\text { curriculum. Both grammar, } \\
\text { language use and goals. }\end{array}$ & & \\
\hline
\end{tabular}




\begin{tabular}{llll}
\hline $\begin{array}{l}\text { How } \\
\text { communicate in } \\
\text { target situation }\end{array}$ & $\begin{array}{l}\text { The target situation are lovely } \\
\text { to do competition who is the } \\
\text { fastest and the rightest. They } \\
\text { also need equipment material to } \\
\text { support the prior language } \\
\text { focus. }\end{array}$ & $\begin{array}{l}\text { Book } \\
\text { specification }\end{array}$ & $\begin{array}{l}\text { Thecification is an A4 } \\
\text { in which of havel book } \\
\text { layout with dictionary, } \\
\text { combining with several } \\
\text { tasks and exercises. }\end{array}$ \\
\hline $\begin{array}{l}\text { Professional } \\
\text { information } \\
\text { about learner }\end{array}$ & $\begin{array}{l}\text { Tasks, exercises and other } \\
\text { activities are need in English } \\
\text { learning process because the } \\
\text { students ready to receive those } \\
\text { components. }\end{array}$ & \\
\hline
\end{tabular}

\section{Table 1 Needs and Criteria of Suitable}

As described in the previous table, the need analysis focused on English for specific purposes based on the analysis of the situation of the teaching and learning environment. The point is consistent with the theory developed by Dudley-Evans and John, (2011). As for the findings of the interview, those are the ideas expressed by the English teacher.

In terms of results, the study of the interviews conducted by the researcher of the two sources explained that West Kalimantan Malay local culture today has been progressing well although not yet in significant numbers. The researcher conducted an analysis in which potential areas and products of Malay tourism in West Kalimantan that proper as teaching materials. It supports English based on interviews and the result of triangulation process of the findings by checking the literature from various sources consisting of Perpustakaan Daerah of West Kalimantan, Department of Tourism and Economy Creative of West Kalimantan, KUWAS (Komunitas Wisata Sejarah or Historical Tourism Community) and several trusted-internet sources. The quality of information of many sources be a limitation for adding or not in the supplementary material or even though the interviews result explain that all local cultures and Malay tourism are suitable for educational information. The following table describes the tourist spot available in the product.

\begin{tabular}{|c|c|c|c|c|c|c|}
\hline No & & Core Products & No & Suppl & ment Products & \\
\hline 1. & Museum & $\begin{array}{l}\text { 1. Central Museum of } \\
\text { West Kalimantan Barat } \\
\text { Province } \\
\text { 2. Museum of Kapuas } \\
\text { Raya Sintang }\end{array}$ & 1. & $\begin{array}{l}\text { Tourism Office } \\
\text { information }\end{array}$ & $\begin{array}{l}\text { Addresses } \\
\text { government } \\
\text { local office } \\
\text { regions of } \\
\text { Kalimantan }\end{array}$ & $\begin{array}{r}\text { of } \\
\text { tourism } \\
\text { in all } \\
\text { West }\end{array}$ \\
\hline
\end{tabular}




\begin{tabular}{|c|c|c|c|c|c|}
\hline 2. & Palaces & $\begin{array}{ll}\text { 1. } & \text { Kadriyah Palace } \\
\text { 2. Amantubillah Palace } \\
\text { 3. Alwadzikoebillah } \\
\text { Palace } \\
\text { 4. Surya Negara Palace } \\
\text { 5. Al Mukarramah Palace } \\
\text { 6. Ismahayana Palace }\end{array}$ & 2. & $\begin{array}{l}\text { Travel Guide } \\
\text { and travel agent }\end{array}$ & $\begin{array}{l}\text { The names of the travel } \\
\text { company included } \\
\text { members of ASITA } \\
\text { (Association of The } \\
\text { Indonesian Tours and } \\
\text { Travel Agencies) West } \\
\text { Kalimantan }\end{array}$ \\
\hline 3. & Mosque & $\begin{array}{l}\text { 1. Jami' Mosque of Sultan } \\
\text { Syarif Abdurrahman } \\
\text { 2. Agung Jami' Mosque of } \\
\text { Sulthan Muhammad } \\
\text { Tsafuddin } \\
\text { 3. Jami' Mosque of Sultan } \\
\text { Nata } \\
\text { 4. Jami Mosque of } \\
\text { Landak Palace }\end{array}$ & 3. & $\begin{array}{l}\text { Hotels or guest } \\
\text { houses }\end{array}$ & $\begin{array}{l}\text { The names of the hotel } \\
\text { company included } \\
\text { members of PHRI } \\
\text { (Perhimpunan Hotel dan } \\
\text { Restoran Indonesia) } \\
\text { West Kalimantan }\end{array}$ \\
\hline 4. & $\begin{array}{l}\text { Cultural } \\
\text { Events }\end{array}$ & $\begin{array}{l}\text { 1. Festival Budaya Melayu } \\
\text { West Kalimantan } \\
\text { 2. Meriam Karbit festival } \\
\text { 3. Robo'-Robo' ceremony } \\
\text { 4. Faraje' festival } \\
\text { 5. Pontianak Anniversary } \\
\text { celebration } \\
\text { 6. Sampan B Bedar } \\
\text { competition } \\
\text { 7. Kulminasi Day } \\
\text { 8. Festival Budaya Bumi } \\
\text { Khatulistiwa }\end{array}$ & 4. & $\begin{array}{l}\text { Restaurants } \\
\text { included local } \\
\text { culinary } \\
\text { restaurant }\end{array}$ & $\begin{array}{l}\text { Several places that } \\
\text { serves kinds of culinary } \\
\text { of West Kalimantan } \\
\text { especially Malay foods } \\
\text { such as Ikan Asam } \\
\text { Pedas, Pacri Nenas, } \\
\text { Bubur Pedas, Kerupuk } \\
\text { Basah, and Bingke } \\
\text { Pontianak. }\end{array}$ \\
\hline 5. & $\begin{array}{l}\text { Tombs or } \\
\text { Royal } \\
\text { Cemetery }\end{array}$ & $\begin{array}{l}\text { 1. Batu Layang Royal } \\
\text { Tomb } \\
\text { 2. Opu Daeng Manambon } \\
\text { Royal Tomb }\end{array}$ & 5. & Arts and Craft & $\begin{array}{l}\text { 1. Traditional Woven } \\
\text { (Corak Insang and } \\
\text { Traditional Sambas } \\
\text { Woven) } \\
\text { 2. Music and Dance } \\
\text { (Hadrah and Jepin) } \\
\text { 3. Souvenir shop centre } \\
\text { in West Kalimantan. }\end{array}$ \\
\hline 6. & Bridge & $\begin{array}{l}\text { Kapuas Bridge I } \\
\text { (Pontianak) included the } \\
\text { Kapuas River }\end{array}$ & 6. & Transportations & $\begin{array}{l}\text { 1. Public transportation } \\
\text { 2. Private or } \\
\text { Commercial } \\
\text { Transportation. }\end{array}$ \\
\hline
\end{tabular}

\section{Table 2 Tourism Products of West Kalimantan}

Regarding results, the informants agreed that the local Malay culture could be promoted to the world of tourism and information can also be a mean of education for the younger generation and do not forget the history. 


\section{Designing process}

This phase, the researcher elaborates result of analysis phases in a part of outline based on the theory from Graves, (2000) consists of organizing principles, identifying the unit, determining unit, organizing, and sequencing unit. Point a to $\mathrm{d}$ describes these parts.

a. Organizing principles

Specifically, in the context of developing this supplementary material, researcher divides the organization of this book into two core components that are the psychological and pedagogical aspect and the component product of tourism industry. Then, researcher elaborates the two components to the next step in which has a purpose of identifying the material units based on the organizing principles.

b. Identifying the material units

Three components are identified from Richard (2001) theory that material should take into account to the principles of relevance, develop expertise, reputation, and flexibility. Based on four aspects of Richards' theory, the researcher identified two ideas of material content. First, it was based on the view of tourism product content and second was based on the view of pedagogical content.

c. Determining the unit content

This book consisted of six units that completed several tasks and exercises. Determining unit contents are described below.

\section{1) Unit I Introduction}

The first unit of material is intended to introduce the general content of West Kalimantan. It provides information about the map, profile of cities and regencies.

\section{2) Unit II Cultural Sites}

The second unit of this material is intended to deliver information of physical site of monument or traditional houses. The sites are many histories related to the Malay culture.

3) Unit III Festival and Attraction

The third unit of material is intended to deliver information of several cultural events and religious celebrations in which it usually comes at the same time in each year. 
4) Unit IV Art and Craft

The fourth unit of material is intended to deliver information of traditional products, objects, images, music, etc. that are beautiful or that express feeling that usually made by Malay people.

5) Unit V Accommodation and Transportation.

The fifth unit of material is intended to deliver information of place to take a rest, eating, office center, ticketing, and guiding, also transportation used.

d. Organizing and sequencing unit

Organizing and sequencing unit mean that researcher conducted a travel guidebook more detail by dividing it into a few parts. Both for its content and a few other extras.

3. Development Process

The material was developed from the designing unit that was formulated based on the results of needs assessment and standards of competencies and basic competencies for the tenth-grade year students of the vocational high school. The previous stage has presented the organization of each unit. The researcher expanded the richness by inserting texts and particular additional parts. The researcher adapted and adopted many sources in developing the texts.

4. Evaluating Process

a. Product Trial Process

This process has been implemented in two days at SMK Tourism CBK Pontianak. All of the aspects have criteria of acceptableness or goodness of material if each element has the mean score $\geq 2$ because of the range of the Likert scale is among 0 to 4 . The researcher used the total score of each aspect from 50 total participants. However, only 49 questionnaires that can be analyzed because there was one incomplete questionnaire (not-valid questionnaire). The results showed that all the aspect of developing this material was acceptable. It means that the book was suitable for use. Several tables below describe the explanation of each element. 


\begin{tabular}{clccc}
\hline Aspects & \multicolumn{1}{c}{ Purposes of the Questions } & Item Numbers & Mean Score \\
\hline $\begin{array}{l}\text { Principles of The Design } \\
\text { and Development Material }\end{array}$ & $\begin{array}{l}\text { To find out the students' and } \\
\text { teacher' responds to the } \\
\text { appropriateness of the material to } \\
\text { the principles of design and } \\
\text { development materials. }\end{array}$ & & \\
\end{tabular}

\section{Table 3 Mean Score of Principles of Design and Development Material}

From the result of the score that is mean scores are $\geq 2$. It means that the principles of design and development of material are acceptable.

\begin{tabular}{clcc}
\hline Aspects & \multicolumn{1}{c}{ Purposes of the Questions } & $\begin{array}{c}\text { Item } \\
\text { Numbers }\end{array}$ & Mean Score \\
\hline $\begin{array}{c}\text { Types of Task-based } \\
\text { Instruction Task }\end{array}$ & $\begin{array}{l}\text { To find out the students' and } \\
\text { teacher' responds to the } \\
\text { appropriateness of the tasks in the } \\
\text { material. }\end{array}$ & 5 & 2.91 \\
\hline
\end{tabular}

\section{Table 4 Mean Score of Types of Task-based Instruction Task}

From the result of the score that is mean scores are $\geq 2$. It means that the task-based instruction tasks are acceptable.

\begin{tabular}{clcc}
\hline Aspects & Purposes of the Questions & Item Numbers & Mean Score \\
\hline $\begin{array}{c}\text { Criteria of Travel } \\
\text { Guide Book }\end{array}$ & $\begin{array}{l}\text { To find out the students' and teacher' } \\
\text { responds to the appropriateness of the } \\
\text { criteria of the travel guide book. }\end{array}$ & 5 & 3.30 \\
\hline
\end{tabular}

Table 5 Mean Score of Criteria of Travel Guide Book

From the result of the score that is mean scores are $\geq 2$. It means that the criteria of travel guidebook are acceptable.

b. Expert Validation

This section is a part of the evaluation product. All of the aspects have criteria of acceptableness or goodness of material if each element has the mean score $\geq 2$ because of the range of the Likert scale is among 0 to 4 . The results showed that the 
aspect of expert validity was acceptable. It means that the book was suitable for use. Several tables below describe the explanation of each aspect.

\begin{tabular}{|c|c|c|c|c|}
\hline & $\operatorname{Aspect}(\mathbf{s})$ & Purposes of the Questions & $\begin{array}{c}\text { Item } \\
\text { Numbers }\end{array}$ & $\begin{array}{l}\text { Mean } \\
\text { Score }\end{array}$ \\
\hline \multirow{5}{*}{$\begin{array}{l}\text { Process } \\
\text { and } \\
\text { Content } \\
\text { Validity }\end{array}$} & $\begin{array}{l}\text { Relation to syllabus and } \\
\text { curriculum }\end{array}$ & $\begin{array}{l}\text { To find out the suitableness of the } \\
\text { content to curriculum and } \\
\text { syllabus. }\end{array}$ & 2 & 3 \\
\hline & Methodology & $\begin{array}{l}\text { To find out the suitableness of the } \\
\text { content to methodology. }\end{array}$ & 2 & 2 \\
\hline & Suitability to learners & $\begin{array}{l}\text { To find out the suitableness of the } \\
\text { suitability to the learners. }\end{array}$ & 2 & 3.5 \\
\hline & $\begin{array}{l}\text { Physical utilitarian } \\
\text { attributes }\end{array}$ & $\begin{array}{l}\text { To find out the suitableness of the } \\
\text { physical utilitarian attributes. }\end{array}$ & 3 & 3 \\
\hline & $\begin{array}{c}\text { Efficient layout of } \\
\text { supplementary material }\end{array}$ & $\begin{array}{l}\text { To find out the suitableness of the } \\
\text { efficient layout of supplementary } \\
\text { material. }\end{array}$ & 3 & 2.33 \\
\hline
\end{tabular}

Table 6 Mean Score of Relation to Syllabus and Curriculum

From the result of the score that is mean scores are $\geq 2$. It means that the criteria of process and content validity are acceptable.

\begin{tabular}{lllll}
\hline \multicolumn{2}{c}{ Aspect(s) } & \multicolumn{1}{c}{ Purposes of the Questions } & $\begin{array}{c}\text { Item } \\
\text { Numbers }\end{array}$ & $\begin{array}{c}\text { Mean } \\
\text { Score }\end{array}$ \\
\hline $\begin{array}{c}\text { Psychological and } \\
\text { Pedagogical } \\
\text { Validity }\end{array}$ & General content & $\begin{array}{l}\text { To find out the suitableness of the tasks } \\
\text { in the material. }\end{array}$ & 5 & 3 \\
\cline { 2 - 5 } & Skills of English & $\begin{array}{l}\text { To find out the appropriateness the skills } \\
\text { of English (reading, writing, speaking, } \\
\text { and listening) in the material. }\end{array}$ & 10 & 3.5 \\
\cline { 2 - 5 } & Sub-skills of & $\begin{array}{l}\text { To find out the suitableness of the sub- } \\
\text { English } \\
\text { and pronunciation) in the material. }\end{array}$ & 8 & 3 \\
\cline { 2 - 5 } & Exercise & $\begin{array}{l}\text { To find out the suitableness of the form } \\
\text { of exercise with students' activities. }\end{array}$ & 4 \\
\hline
\end{tabular}

\section{Table 7 Mean Score of Psychological and Pedagogical Validity}

From the result of the score that is mean scores are $\geq 2$. It means that the criteria of psychological and pedagogical validity are acceptable. 


\begin{tabular}{cllclc}
\hline \multicolumn{2}{c}{ Aspect(s) } & Purposes of the Questions & $\begin{array}{c}\text { Item } \\
\text { Numbers }\end{array}$ & $\begin{array}{c}\text { Mean } \\
\text { Score }\end{array}$ \\
\hline $\begin{array}{c}\text { Component } \\
\text { Product of } \\
\begin{array}{c}\text { Tourism } \\
\text { Industry }\end{array}\end{array}$ & Core product & $\begin{array}{l}\text { To find out the availability of the core } \\
\text { products of tourism in the material. }\end{array}$ & 3 & 4 \\
\cline { 2 - 6 } & $\begin{array}{c}\text { Supplement } \\
\text { product }\end{array}$ & $\begin{array}{l}\text { To find out the availability of the } \\
\text { supplement products of tourism in the } \\
\text { material. }\end{array}$ & 3 & 3.33 \\
\hline
\end{tabular}

\section{Table 8 Mean Score of Component Product of Tourism Industry}

From the result of the score that is mean scores are $\geq 2$. It means that the criteria of the component product of tourism industry are acceptable.

The researcher believes that from those scores above are not enough for making an excellent material because the critical point is on the feedback. The following table below are the list of feedback.

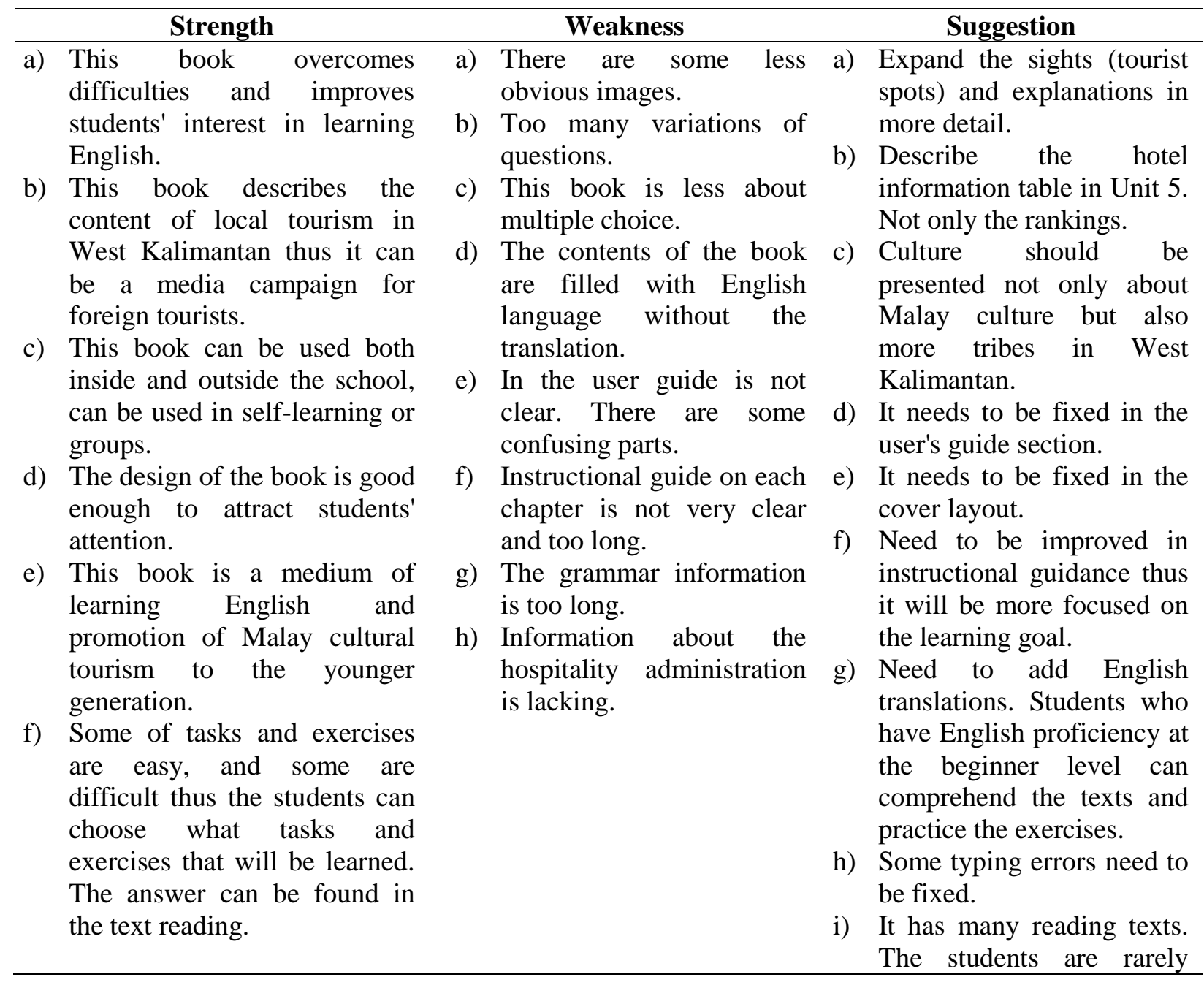


difficult to comprehend all the texts.

j) Add the grammar guide of anonym and synonym.

\section{Table 9 Feedback}

\section{Revision Process}

This section is a final step of this study. Revision process based on product evaluation process consisting of product trial and experts' validation process. Stressing to the weakness and the suggestion from those participants, the researcher respond those particular items and make a revision based on the list below.

a. Simplify the instruction in each task and exercise.

b. Not adding translations but instructing students to provide English-language dictionaries while studying this book and directing teachers to facilitate understanding of difficult words in users' guide. It is intended that students are exposed to English as often as possible to familiarize and motivate them to memorize new vocabularies.

c. Selecting photos that are less clear and if necessary replace or edit them to make it more bright and exciting.

d. Improve the user guide becomes more evident and systematic.

e. Fixed the cover layout by removing images that do not represent the contents of books on Malay tourism.

f. Fixed typing errors and typing errors in each unit.

g. Perfecting the forms of task and exercise with matching test, multiple choice, fill in the blanks, short essay (opinion writing), and so on.

h. Explaining information about hotel accommodation on unit 5 is not just about classification information but how VTS can be a useful travel guide to deliver hotels in West Kalimantan.

i. The limitation of this study is the book focuses on represents information about Malay tourism. The development of other cultural tourism will be one of the input suggestions for other practitioners and researchers.

j. This book is again only as a supplementary English material. Students are not forced to understand the all available texts. Students can choose which ones to learn which are not dependent on the needs. 
k. The guide of synonym and antonym not be inserted in the product because that point already explained explicitly in the prior book.

Developing English teaching material, evaluating and revising the teaching materials is a tangible step to meet students' learning needs who have learning goal specifications. Experts have already mentioned that ESP should adopt the needs of teachers and students to support learning objectives, institutional goals, which may be different from those of general English (Dudley-Evans and John, 2011; Johns and Machado, 2001; Scrivener, 2005). Thus, this situation prompts the school to take time, cost, energy, and effort to develop its teaching materials regarding support the purpose of the institution.

This study is provided to develop a supplementary English material for the tenth-grade year VTS using the design and development methodology that refers to the product and the tool design. A supplemental material has the function to enhance the elements that are not available on the part of course books or prior textbooks (Mendiknas RI, 2008; \& Tomlinson, 2011).

In every phase, it has a substantial role that it is not able to be separated from each other. First, the analysis process was intended to obtain information on learning needs. Second, the design process was expected to create an outline before the product is developed. Third, SMK Pariwisata CBK which is a research site, especially tourism that has two departments of hospitality administration and travel agency. In the English subject, the teacher used the primary teaching materials that are perceived as not enough to represent the objectives of the English lesson. They need teaching materials that synergize between what is in the field with the theory that is in the classroom. This phenomenon is in line with research conducted in Hongkong against vocational students. The condition in the area is not ideal as same as in the school (Hua, Tzu-Ling \& Beverton, Sue, 2013). There is inequality between those settings that needed adjustment of curriculum, teaching materials and recommending new policies (Hua, Tzu-Ling \& Beverton, Sue, 2013)

The result indicated that the suitableness of the teaching material is a supplementary material that complements the needs of the (Dudley-Evans and John, 2011) aspect and the tourism aspect (Barrudy \& Mardiono, 2016). Referring to the theory of Munsters and Clumbis (2006) stated that the tourism industry has two main categories of products namely the primary product (in the form of physical tourist destinations) and complementary products (facilities, and infrastructure that support and meet the needs of travelers). This book 
has been designed by describing the information of Malay tourist attractions, cultural activities and tourism support facilities that must be in the educational information for VTS.

This study supports the local contents by providing several activities (tasks and exercises). The actions should be inserted in the materials because those parts help the development of students' skills (Nunan 2004; Subekti 2014; \& Willis 1996). By giving tasks, students practice the instruction and interact each other to raise the learning goal (Tomlinson, 2011). A task makes the system more straightforward to achieve the goals of language learning because the setting is designing in real-situation (Branden, 2006). Moreover, students have more opportunities to master the language with process-oriented, blend theory and personal experience, and synergize knowledge gained in the field by learning the language in the classroom (Nunan, 2004).

\section{CONCLUSION}

To sum up, the researcher believes that the product in the form of travel guidebook can be a suitable supplementary material to fulfill, enhance, and motivate students to be more active in learning English. The product of a supplementary material of Malay tourism in West Kalimantan for the tenth year students at SMK Pariwisata CBK Pontianak comes in the form of a book that is designed as a package of tourism guidebook consisting of several tasks and exercises to cover learning of ESP, mainly related to the tourism industry. It can be used not only for teaching English but also for introducing and promoting social-cultural information of Malay tourism in West Kalimantan for the tenth year students at SMK Pariwisata CBK Pontianak. Based on the response of implementation and validation process is considered that the travel guidebook of Malay tourism in West Kalimantan is suitable for a supplementary material of English learning for VTS. The teacher, students, and the validator responded the book positively and provided feedback for the improvement of this book.

The researcher, therefore, in the wise way of expectation may suggest to educators, expertise, other researcher and stakeholders. The first suggestion belongs to English teacher that the product can be used maximally in supporting English learning process for VTS. English teachers are expected to include local values of Indonesia and introduce them in English versions. The second suggestion also refers to educational researchers. Taking a part of preservation the Malay cultures and inviting local researchers to create different products of supplementary materials supporting Kalimantan life is a tremendous and concrete contribution. They are expected to promote the success of ESP learning activities in Asian 
countries, particularly Indonesia (Pontianak). The last is to the stakeholders. Accommodating the existence of the concepts and the goals of the background of vocational schools is the very wise and fair policy in The Ministry of Primary and Secondary Education (Kementerian Pendidikan Dasar dan Menengah). It is necessary to evaluate the synergism between the needs in the field and the materials practice in the classroom, especially in the English subject at vocational schools. Also, it is required to do quality control of textbooks distribution in the marketing area. 


\section{BIBLIOGRAPHY}

Ahyat, I. S. (n.d.). Dinamika dan Perkembangan Budaya Melayu Kalimantan Barat. Prosiding The 4Th International Conference on Indonesian Studies Unity, Diversity and Future. Retrieved from https://icssis.files.wordpress.com/2012/05/0910201235.pdf.\%0A\%0A

Barrudy, M. E., \& Mardiono, B. (2016). Perancangan Buku Referensi Travel Pariwisata Pulau Bawean. JURNAL SAINS DAN SENI ITS, 5 (2 (2016)), 2337-3520-928-152.

Branden, K. V. (2006). Task-Based Language Education. UK: Cambridge.

Christou, E. (2005). Heritage and Cultural Tourism: A Marketing-Focused Approach. In M. Sigala, \& D. Leslie. International Cultural Tourism: Management, Implications, and Cases, 3-15.

Creswell, J. W. (2012). Educational Research (Planning, Conducting and Evaluating Quantitative and Qualitative Research). Boston: Pearson Education.

Dudley-Evans, T., \& \& M. J. St John. (1998). Developments in English for Specific Purposes. A multi-disciplinary approach. Cambridge.

Dudley-Evans, T., \& John, M. J. (2011). Developments in English for Specific Purposes. UK: Cambridge.

Graves, K. (2000). Designing Language Courses: A Guide for Teacher. New York: Heinle \& Heinle.

Hua, T.-L., \& Beverton, S. (2013). General or Vocational English Courses for Taiwanese Students in Vocational High Schools? Students' Perceptions of Their English Courses \& Their Relevance to Their Future Career. Springer, 12, 101-120.

Johns, A. M., \& Machado, D. P. (2001). English for Specific Purposes: Tailoring Courses to Student Needs and to the Outside World. In M. C. Murcia. Teaching English as a Second or Foreign Language, 3th Editio, 43-54.

Kasmawita, Ikhsanuddin, \& Salam, U. (2015). Developing Alcon-Pro for English Teaching Learning at SMAN 1 Singkawang. Jurnal Pendidikan Dan Pembelajaran, 4(9).

Kothari, C. R. (2004). Research Methodology; Methods and Techniques (Second Revised Edition). India: New Age International Publishers.

Mendiknas, R. (2008). Peraturan Menteri Pendidikan Nasional Republik Indonesia Nomor 2. $B u k u$. Jakarta Indonesia: Menteri Pendidikan Nasional RI.

Munsters, W., \& de Klumbis, D. F. (2005). Culture as A Component of Hospitality Product. In M. Sigala, \& L. David. International Cultural Tourism: Management, Implications and Cases, 26-39.

Nunan, D. (2004). Task-Based Language Teaching. UK: Cambridge. 
Pariwisata, D., \& Kalbar, E. K. (2014). Usaha dan Sarana Kepariwisataan Kalbar. Pontianak: Dinas Pariwisata dan Ekonomi Kreatif Kalbar.

Richard. (2001). Language Curriculum Design.

Richey, R. C., \& Klein, J. D. (2007). Design and Development Research Methods, Strategies, and Issues. New Jersey: Lawrence Erlbaum Associates.

Ridwan, S., \& U., S. (2014). Designing Samples of Reading Materials based on CTL by Using Local Legends of Dayak Pesaguan. Jurnal Pendidikan \& Pembelajaran, 3(3).

Scrivener, J. (2005). Learning Teaching: A Guidebook to English Language Teachers. Macmillan Education.

Subekti, S. (2014). Developing Task-Based Material For English Conversation (EC) Program at Grade Eleven SMAN Plandaan Jombang. In The 3rd UAD TEFL International Conference 2014 "Materials Development in Asia and Beyond: Directions, Issues, and Challenges” (pp. 1076-1085). Yogyakarta: English Education Department, Universitas Ahmad Dahlan.

Tomlinson, B. (2007). Developing Materials for Language Teaching. London: London: Continuum.

Tomlinson, B. (2011). Material Development in Language Teaching. Uk: Cambridge.

Tourism, \& Province, C. E. S. W. K. (2014). West Kalimantan Potential Tourism Profile. Pontianak: Tourism \& Creative Economy Service West Kalimantan Province.

Ulfa, K. (2015). Designing ESP Materials For Tourism Students of Akademi Pariwisata Medan. Pelita Informatika Budi Darma, 69-75. 
Wahyukti, T., \& Pujiatno, A. (2015). Developing an English Modul in Particular Matter of Speaking Skill in Terms of Tourism for The Tenth Grade Students of State Vocational High School. In Seminar Nasional Hasil - Hasil Penelitian dan Pengabdian LPPM Universitas Muhammadiyah Purwokerto. Retrieved from http://download.portalgaruda.org/article.php?article=363100\&val=7672\&title=PENGE MBANGAN MODUL PEMBELAJARAN BAHASA INGGRIS UNTUK KETRAMPILAN BERBICARA (SPEAKING) BERDASARKAN LINGKUNGAN DI SEKOLAH MENENGAH KEJURUAN.

Willis, J. (1996). A Framework for Task-Based Learning. Harlow: Longman. 